\title{
Geological Survey, Gitology, and Geophysical of Deposit Tighmart (High Atlas Demnat)
}

\author{
Wafik Amina, Professor \\ Faculté des Sciences Semlalia, Université Cadi Ayyad, Département de \\ Géologie, Guéliz Marrakech, Morocco \\ Najine Abdessamad, Professor \\ Ouzerbane Zakaria, Doctor \\ Radouani Fadoua, Doctor \\ Faculté des Sciences Semlalia/ Université Cadi Ayyad, \\ Département de Géologie, Marrakech, Morocco
}

\begin{abstract}
The copper site Tighmart, study area is located about $27 \mathrm{~km} \mathrm{NNE}$ of the city of Demnate in the Central High Atlas. On a stand dominated by Devonian shales and sandstones with limestone benches centimeter, rests a cover Triassic (sandstone, red clay with discontinuous basalt flows) and Jurassic (Lias carbonate bars, based on consistent training gypsiferous lower Lias). The set is structured faulted anticline and eroded. Electrical tomography has been used in order to characterize the structural elements that can promote the introduction of the copper, and the mineral density. This mineralization is concentrated locally in metric nodes, formed by the junction of the $\mathrm{N} 70^{\circ}$ faults and $\mathrm{N} 40^{\circ}$. This is very crushed zones decametric extension and where there is a large concentration of chalcocite associated with malachite and azurite rarely. In general, two areas have been identified on both sides of the old gallery: - The southern part crossed by the thalweg shows the dolerite attributed resistant levels through which the levels of oxides and hydroxides of iron and aluminum at depths of 8 to $13 \mathrm{~m}$. This part of the sector does not really present significant reserves given that no continuity was confirmed. - The northern part of a very rugged topography presents no surface mineralization index. However, electrical tomography profiles in this sector show large anomalous beaches right pockets found in the gallery. The examination of the values of apparent resistivity advocates appearing mineralization from $23 \mathrm{~m}$ deep.
\end{abstract}

Keywords: Copper, Tighmart, High Atlas, ore deposits 


\section{Introduction}

After former mining from the Middle Ages and the 16th century in the High Atlas, especially targeted to the iron, silver and copper, geological exploration begins in the 19th century. Several French expeditions, English and German discovered North Africa for Geological and Mining geographical research. The first subdivision in the Moroccan High Atlas mountain system, Middle Atlas and Anti-Atlas or Little Atlas (RITTER 1822 in the Lowner $200 *$ ) was performed.

During the 50s, 60s and 70s, research has referred stratigraphy, paleontology and paleogeography of the Atlas systems. For the Central High Atlas there mainly work on the Jurassic DUBAR (1962-1978), CHOUBERT \& FAURE-MURET (1962) and DU DRESNAY (1963-1988). Later Septfontaine (1984) proposed a detailed biozonation Lower Lias, and average high Atlas by imperforate foraminifera .. Sedimentology "red coats" Triassic and Jurassic is evidenced by LORENZ (1976), and later in particular by MATTIS (1977) and MANSPEIZER (1976-1978), who dated the basalt flows by radiometry.

Despite a large amount of work on the geology of the High Atlas North side results remain fragmented and does not provide the expected solid evidence of metallogeny in the High Atlas. Except in the inventory index, typology, continuity, morphology, extension, texture and mineralogy are less well known.

The aim of the work on this area is limited to ensure the extension of the copper index. We undertook a geological, geophysical and metallogenic study in the copper site Tighmart to define the main structural elements and gitological governing the establishment of the mineralization and to estimate the reserves that could be exploited.

\section{Geographic Setting}

The Tighmart copper deposit is located in the Central High Atlas, 27 $\mathrm{km}$ as the crow flies from the NNE of the town of Demnate (topographic map at 1/50000 from Tifni) (Figure 1). Access to the cottage is via the asphalted road Demnate - Ouarzazate, at the Douar de Tighmat, a $4 \mathrm{~km}$ driveable trail to the left.

The Central High Atlas (MICHARD 1976) or High Atlas limestone (Mattauer 1977) limited by the cross-Marrakech Ouarzazate in the west, and the valley of the Oued $\mathrm{Ziz}$ east. Here, the bedrock is rarely visible, and there is little that outcrops of the Mesozoic cover, called "Atlas pleated coverage," including sediments form characteristic series. The Permo-Triassic red terrigenous deposits are topped by white lower Jurassic carbonates. Middle and Upper Jurassic, there are still red terrigenous deposits, this time strongly 
thickened. The few outcrops of Cretaceous and Tertiary often eroded are stored only on the edge of the channel or the center of the syncline.

Furthermore, we find the Triassic and Liassic basalts and alkaline gabbros of Jurassic and Cretaceous age. These show a thinning of the continental crust by distension (HAILWOOD \& MITCHEL, 1971).

After the absolute dating of basalt flows (BARDON 1978, HAILWOOD 1971, and WESTPHAL 1979), there especially pollens, which are used to classify stratigraphically red beds. A later work in the red beds of the High Atlas, demonstrated the impossibility of dating with palynomorphes found (MOHR \& SEUFERT 1987). This research conjured only depositional environment: a semi-arid to arid deltaic environment with periodic rain. New studies show the previously undertaken research on charophyta in Aptian of the eastern High Atlas (Feist et al. 1999) and Jurassic-Cretaceous in the limit of the Central High Atlas (HADDOUMI et al. 2002 and 2008).

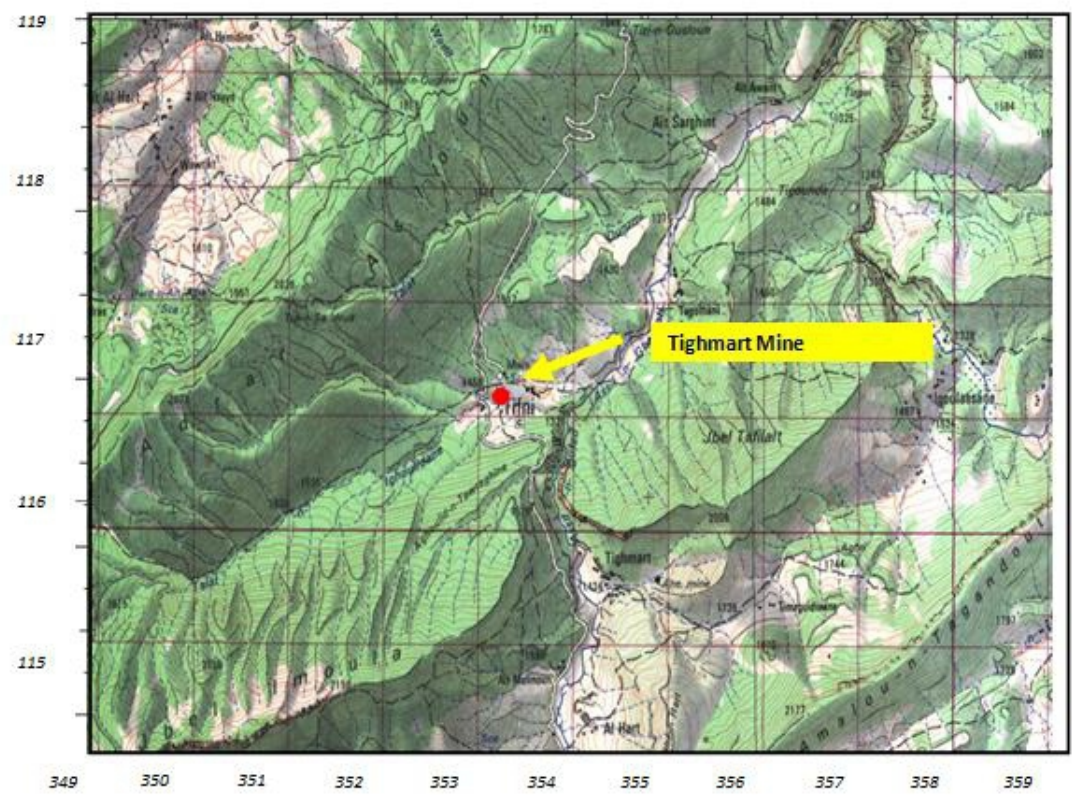

Figure 1 : Situation of the Tighmart copper mine (Extracted from the topographical map at $1 / 50000$ of TIFNI).

Outcrops are abundant lithology and stratigraphy as well as their have been many detailed research. By cons, sedimentary witnesses Triassic and the current interval of the final Cretaceous to Recent remain geographically restricted. Here, there is still a lack of detailed information.

Löwner, (2009), adopted a synthetic form of nomenclature five major specific lithostratigraphic units; borrowed from the geological maps of existing Atlas area, including:

- Geological Map of Morocco, Sheet 2 (Rabat) 1: 500.000th (CHOUBERT 1957) 
- The Afourer sheet 1: 100,000th (ROLLEY 1978)

- Geological Map of Morocco, 1: 1.000.000ième (HOLLARD 1985)

- The Azilal sheet 1: 100,000th (JENNY 1985)

- Beni Mellal sheet 1: 100,000 ${ }^{\text {th }}$ MONBARON 1985)

- The Demnat sheet 1: 100,000th (The MARREC 1985)

- The Imilchil khenifra South-sheet 1: 100,000th (Fadile 1987)

- The Zawyat Ahançal sheet 1: 100,000th (JOSSEN 1990).

These are the following successive units:

- The ante-Jurassic (Permian-Triassic)

- Jurassic carbonates (Hettangien to Bathonian)

- Red beds (Bathonian to Barremian)

- The non-basal Cretaceous (Aptian to Turonian)

- The uppermost Cretaceous and Cenozoic (Senonian to Present).

\section{Structural evolution of the Central High Atlas}

The High Atlas is a typical intracontinental chain (CHOUBERT \& FAURE-MURET 1962 MICHARD 1976 Mattauer et al. 1977 Souhel 1996). This fact is reflected in particular by the lack of ophiolites of flysch, a strong regional metamorphism, and granitoid (Jacobshagen 1986). This area, narrow, is generally elongated west-southwest - east-northeast and is the southernmost part of the Alpine chain peri-of mediterranean (Souhel 1996). The Hercynian substratum is often masked by a Mesozoic or Cenozoic discordant coverage. Polyphase compression (Mattauer 1977) has affected most of the Mesozoic series and the ante-Mesozoic basement, leading to folds, reverse faults and discontinuities from the Cretaceous. The uprising of the High Atlas is the result of a structural inversion from the Cretaceous and Cenozoic, during which the post-Hercynian folded cover was peeled off and the Triassic detrital. Because of these deformations, the High Atlas is crisscrossed by broad synclines flat bottom, filled with thick Jurassic and Cretaceous series, which are often heavily eroded. However, the anticlines are acute, narrow, straightened, abrupt and often overlapping on their borders. This is an axis folds network $\mathrm{N} 80^{\circ} \mathrm{E}$, which are arranged for the greater part in step (Jacobshagen 1986). These anticlines show essentially the Lower Lias limestone thick with locally intruded by Jurassic-Cretaceous magmatic rocks.

The ejective style of the High Atlas (STETS \& Wurster 1982, Jacobshagen 1988, GIESE \& Jacobshagen 1992, PIQUE 1993, Laville 2004) is responsible for a characteristic overlapping range north verging on the northern and southern border on the southern border. Shortening the authors seems to be modest with 10-15\% (BREDE et al. 1992) is strong (Brunet et al. 2003). The division into sedimentary formations adopted (see Figure 
I.1.1) can be considered as representative for the northern edge of the Central High Atlas and take into account the great cycles terrigène-sailors following:

- Deposits of Permo-Triassic red beds 1st intercalation terrigenous

- The carbonate platform liassique

- Local deposits of red beds Toarcian 2nd intercalation terrigenous

- The carbonate platform Dogger

- deposits red beds Dogger and Lower Cretaceous 3rd intercalation terrigenous

- Local carbonate platform of the Aptian

- The deposits of the Lower Cretaceous red beds 4th intercalation terrigenous

- The carbonate platform of the Cenomanian-Turonian

- The deposits of the Upper Cretaceous red beds 5th intercalation terrigenous

- The carbonate platform Senonian

Although the evolution of the Intermountain chain since the Triassic rifting is indisputable, there still uncertainties in detail on copper mineralization and the role of the "red coats", until now, still raise discussions about the genetic relationships between mineralization and sedimentary characteristics litostratigraphiques, paleogeographic and structural in the High Atlas in general, and in particular Tighmart. The lodging of Tighmart is hosted in Triassic formations Jbel Tafilalt and is part of the anticline N'Tighli. The formations encountered are organized into a mega-structure means anticlinal axis NE-SW with a dip to the north. They are controlled by a fault system oriented NE-SW in the heart of the anticlinal ridge, making flush red clays and triassic basalt.

\section{Lithostratigraphic study}

Due to the small amount of data on the site, in addition to the geological map of Morocco in 1: 100000 Demnat sheet (The MARREC 1985), we considered the former research (and CHOUBERT FAUREMURET, 1962) and latest on the base (Hoepffner et al., 2005) and coverage of the High Atlas; including the Triassic (LORENZ 1976 Laville $1991 \mathrm{EL}$ Arabi et al. 2006), the Lower Lias carbonate (SEPTFONATINE 1986 JENNY 1988 Souhel et al. 2000 CHAFIKI et al. 2004, CANEROT et al. 2002), continental sediments of the Dogger, ie the "continental Jurassic" (JENNY 1981 Souhel 1996 ANDREU 2003) and Cretaceous (Souhel 1997 CHARRIERE 2005 HADDOUMI 2008 ETTACHFINI 2008).

In Tighmart sector, lithostratigraphic series includes the base up the following formations (Fig. 2):

- A Devonian rocks: it is flush with the heart of an anticline in fault. It is dominated by shales and sandstones in which, 
interspersed with benches centimeter detrital limestones. The Devonian marks the beginning of the Variscan compression (Hoepffner et al., 2005)

- A Mesozoic cover:

- Trias: it is dominated by detrital sediments, mainly sandstones and red clays. In the Triassic appears discontinuous basalt flows.

- The Jurassic in the study area, the Jurassic is represented mainly by carbonate bars Lias, based on consistent gypsiferous formations of Lower Lias.

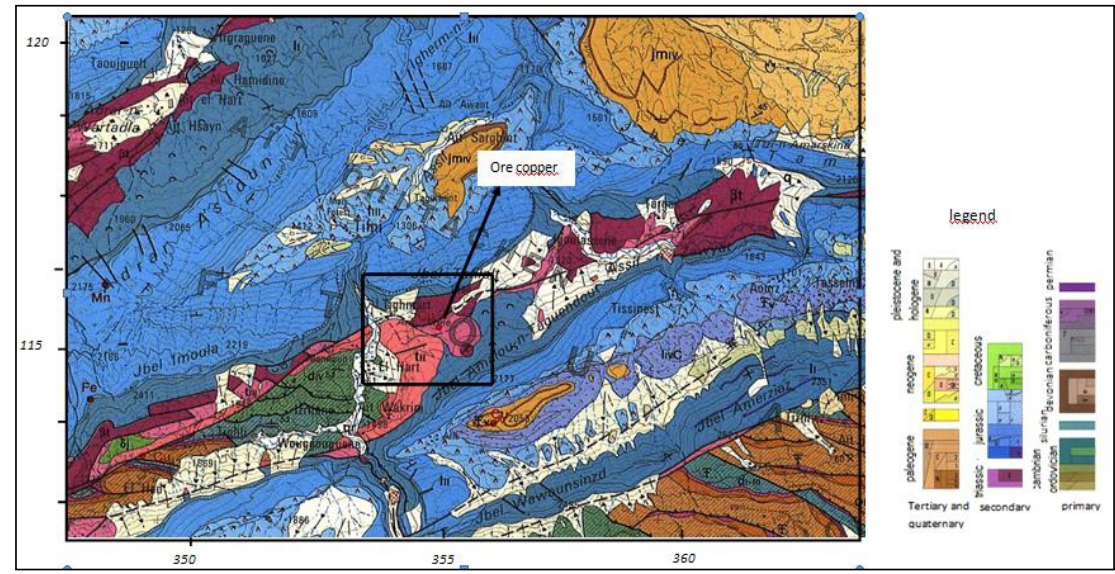

Figure 2: Geology of the region Tighmart Map reduced to a quarter for the sake of presentation (From the geological map of Morocco in 1: 100000 Demnat sheet (LE MARREC 1985)

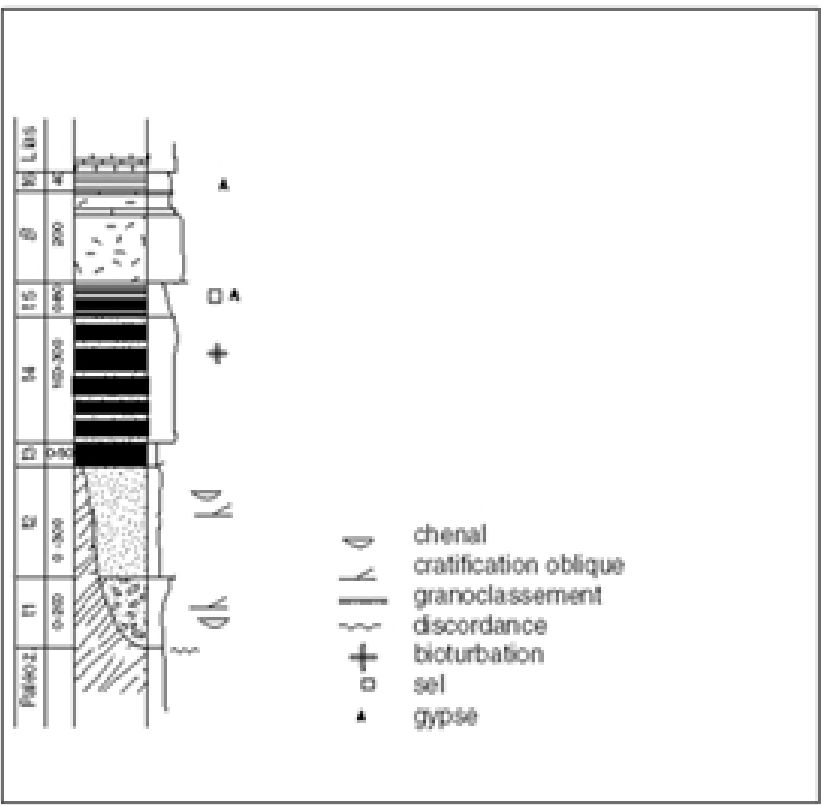

Figure 2: Synthetic log of the study area, Demnat (Le marrec1979). 


\section{Geological study}

Tighmart sector is part of the anticlinal structure n'Tighli. In this sector the series is generally dipping $45^{\circ}$ north. In addition, this ductile deformation appears brittle deformation evidenced by a mean direction of fault network $\mathrm{N} 70^{\circ} \mathrm{N} 40^{\circ}$ and $\mathrm{N} 130^{\circ}$. The structures $\mathrm{N} 70^{\circ}$ and $\mathrm{N} 40^{\circ}$ are precocious compared to $\mathrm{N} 130^{\circ}$ structures as are intersecting.

Unlike many copper deposits of the High Atlas which are hosted in red and white sandstone lenses at the base of Red Layers Lower Cretaceous and classified type Red Bed, such as those of Tansrift and Ait Attab (Ibouh et al. 2011) ; The copper mineralization is hosted Tighmart mainly in Triassic basalts. These basalts are in the form of massive hectometric lenses and having a decametric power. Locally, we note the presence of a layered structure embodied by centimeter to decimeter levels dolerite. (Fig. 2, Photo $1-2)$

The copper mineralization is in the form of a main body, which corresponds to a grinding zone (mega fault zone), 1 to $3 \mathrm{~m}$ power and more than $700 \mathrm{~m}$ across. This mineralized structure has a dip of $45^{\circ}$ to the NW (Photo 2). Locally appear centimeter massive levels of iron oxide (Photo) reflecting a characteristic banded structure in basalts.

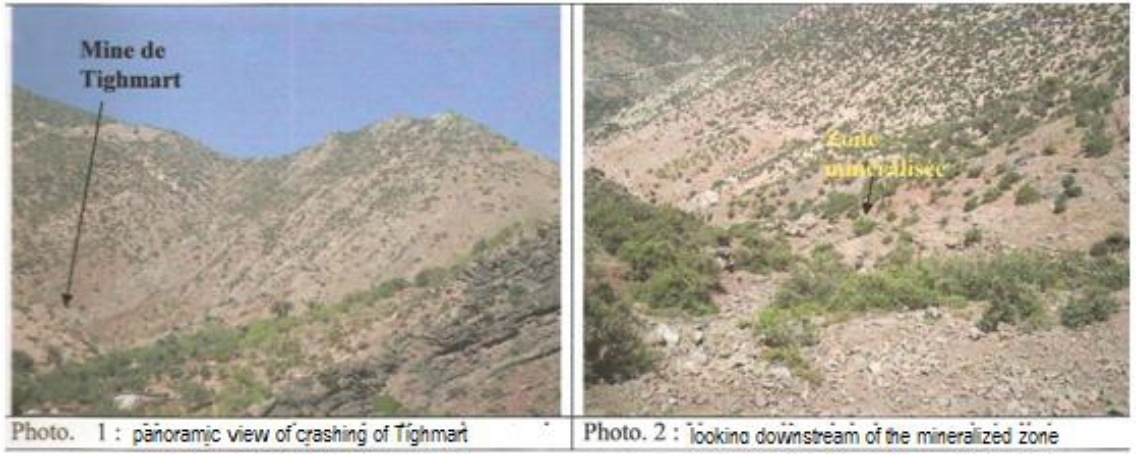

The copper mineralization occurs as disseminated and veneer in basalts (photo $4 \& 5$ ). Most often, it is the filler late fractures. It has a mineralogy dominated by carbonates and copper sulphides (malachite, azurite and chalcopyrite) associated with iron oxides and hydroxides (hematite, goethite) (photo $4 \& 5$ ). Secondary alterations of structures are very characteristic with a predominance of concretions and nodular structures.

The copper mineralization is mainly controlled by the operation of the mega structure of average orientation flaw $\mathrm{N} 70^{\circ}$ with a dip of $50^{\circ}$ to the north (Photo. $1 \& 5$ ). This mineralization is concentrated locally in metric nodes, formed by the junction of the $\mathrm{N} 70^{\circ}$ faults and $\mathrm{N} 40^{\circ}$. This is much crushed zones decametric extension and where there is a large concentration of chalcocite associated with malachite and azurite rarely. 


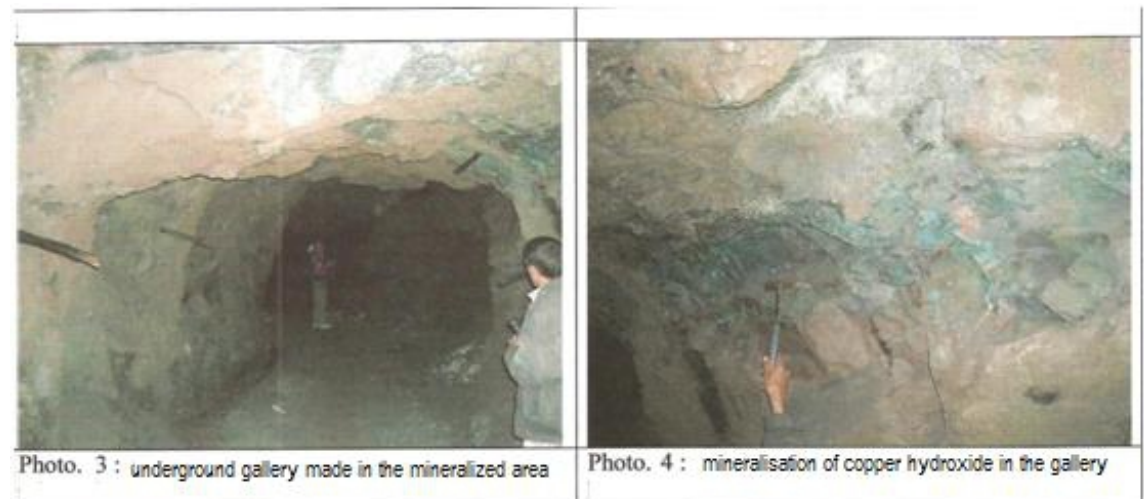

In addition to the structural control of the mineralization, there is a local lithological control of the latter. Indeed, this mineralized horizon appears located on top of a basalt flow materialized by a very fine sediment levels and rich in iron oxides (photo5). This sediment level cashes much of mineralization characterized by the abundance of oxides and hydroxides of copper. Most often appear mineralized fragments (centimeter and decametric) of this sedimentary facies packed in basaltic flows (photo 6).

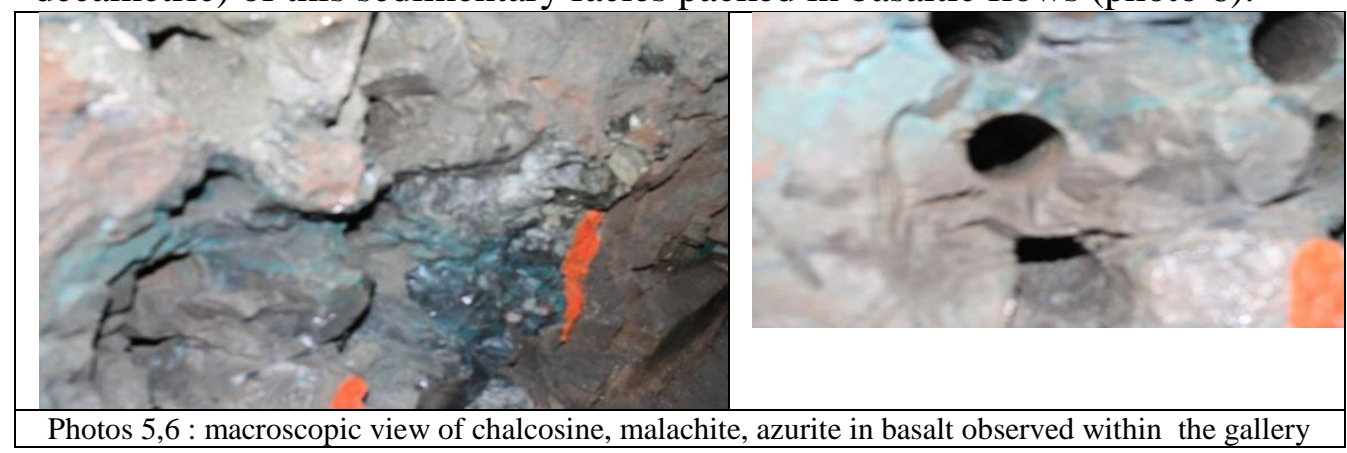

The rheological difference between sedimentary and basaltic level, favorised the of this fault zone, having replayed and remobilising primary metalliferous stock, giving rise to current copper mineralization.

\section{Geophysical study}

Electrical tomography was used in order to characterize the geology and structural elements that can promote the development of copper and of course to determine the structures of mineralization in place, as well as mineralization density. Tomography profiles were positioned perpendicular to the main direction of the mineralized structures with clues surface. To determine the geometry and measurement device configuration to adopt, we started with a geological field reconnaissance particularly in order to have an idea about the thickness of the training involved. These investigations have led us to opt for a small electrode spacing $(5 \mathrm{~m})$ with the aim to have 
sufficient lateral resolution on the one hand and on the other to choose the pole-pole configuration that allows to gain in depth investigation through the electrode placement to infinity (Fig. 4).

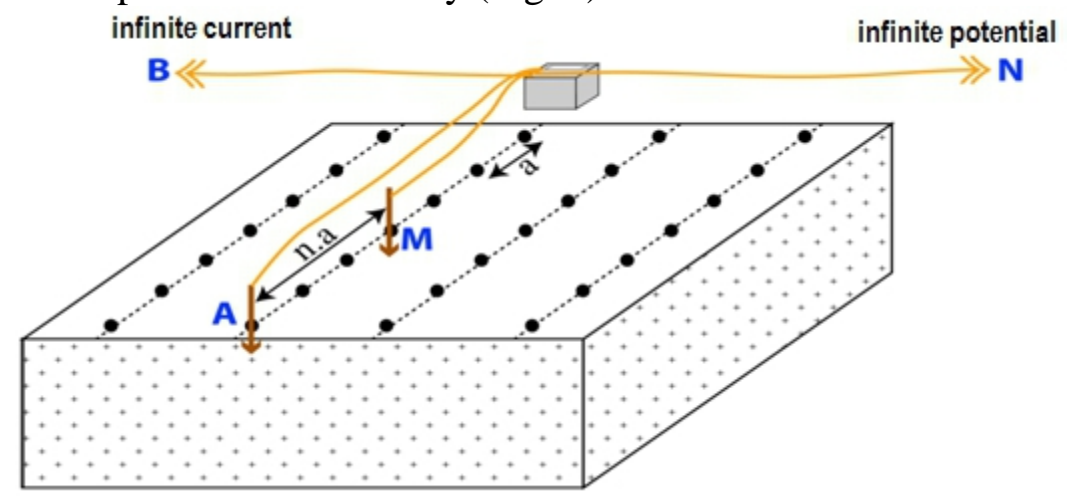

Figure 5: Schematic of the implementation of a survey of electrical tomography Pole-Pole configuration

The measurements were performed using a resistivimeter designed by Iris Instruments, according to a grid having $5 \mathrm{EW}$ profiles and 9 NS profiles (Fig. 2). EW lines that are perpendicular to the stratification is to determine the depth continuity of the mineralized discontinuities that visibly show a slight dip to the east. By cons, NS bedding parallel lines have been planned with the aim to highlight any resistant mineralization. In general, the study area was divided into two sectors for better investigation:

- The sub sector I: including the southern part and southeast

- The sub sector II with the northern part and Northwest.

A total of 14 panels resistivity were carried out on the whole area. These measurements were performed to meet two objectives:

- Cover a systematic way the previously selected area

- Report on the importance of existing mineralization in the surveyed area. In this aspect, it is important to note that no measures equidistance between the stations and the orientation of the profiles was revised as the work progresses. This will maximize the information and make effective every step. The map in Figure 6 shows the location of all profiles made in Tighmart site: 


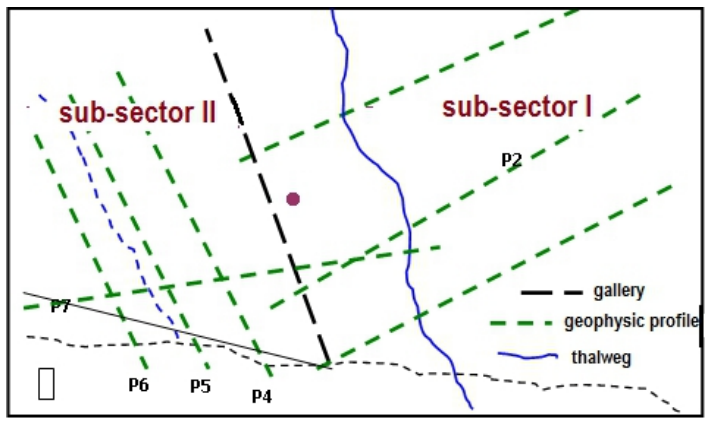

Figure 6: Site Map geophysical profiles

\section{Results}

Results geophysics are shown in figures (7 to 14) in the form of pseudo-sections of apparent resistivity and resistivity models of the actual basement obtained by inversion of the data. A first review of the overall results revealed the existence of significant variations in the electrical resistivity of the subsurface reflecting the heterogeneity it. The interpretation of such changes requires knowledge of the geology of the study site. Schematically, the area covered by the geophysical survey is formed by:

- Triassic: it is dominated by detrital sediments, mainly sandstone and red clay. In the Triassic appears discontinuous basalt flows.

- Jurassic: in the study area, the Jurassic is represented mainly by carbonate bars Lias, based on consistent gypsiferous formations of Lower Lias

- The Devonian: it is flush with the heart of the anticline with faulted formations of Lias. It is dominated by shales, sandstones in which interspersed centimeter beds of limestone.

Correlations between different profiles were performed and the results of the geophysical investigation were confronted with the data of the local geology. Abnormalities attributed to the mineralization appear discontinuously and highly localized. This confirms that the genesis of ore bodies was carried out thanks to tectonic discontinuities. The faults detected on profiles and verified in the field have also replayed later to deform the mineralized structures in place. Two areas have been identified on both sides of the old gallery:

- The southern part crossed by the thalweg shows resistance levels attributed to the dolerite crossed by levels of oxides and hydroxides of iron and aluminum at depths of between 8 and 13 meters.

Profiles 1, 3 and 7 show no continuity with mineralization observed in the old gallery, which explains that this mineralization exists only as disseminated and veneer in dolerite. Most often, it is the filler late fractures. It has a mineralogy dominated by the oxides and hydroxides of copper (malachite, azurite and chalcopyrite). The copper mineralization is associated 
with iron oxides and hydroxides, which are represented by hematite and goethite. This part of the sector does not really present significant reserves given that no continuity was confirmed.

- The northern part of a very rugged topography presents no surface mineralization index. However, electrical tomography profiles in this sector show large anomalous beaches right pockets found in the gallery. The examination of the values of apparent resistivity advocates appearing mineralization from 23 meters deep. We recommend making the point shown on the diagram of a recognition survey block to confirm the results of the geophysical.

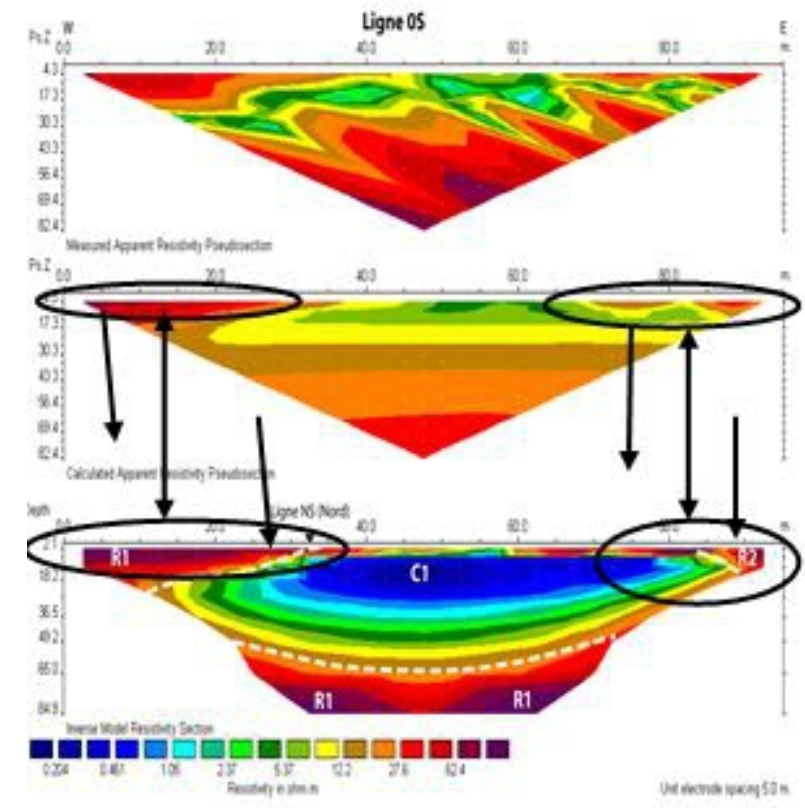

Figure 7: Electrical tomography survey: Line OS

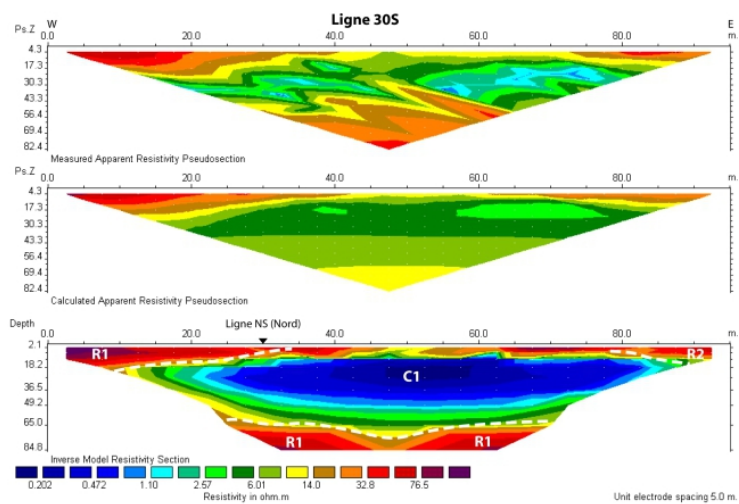

Figure 8: Electrical tomography survey: Line $30 \mathrm{~S}$ 

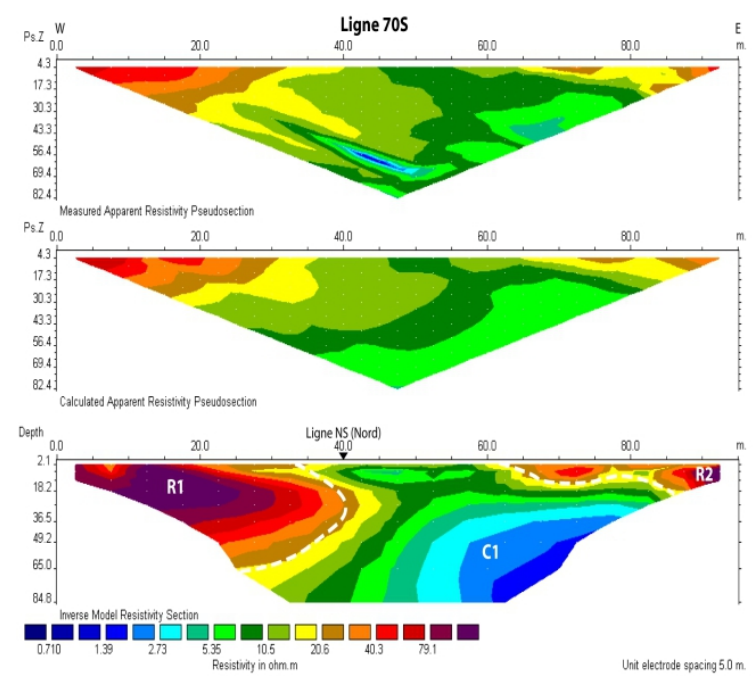

Figure 9: Electrical tomography survey: Line $70 \mathrm{~S}$

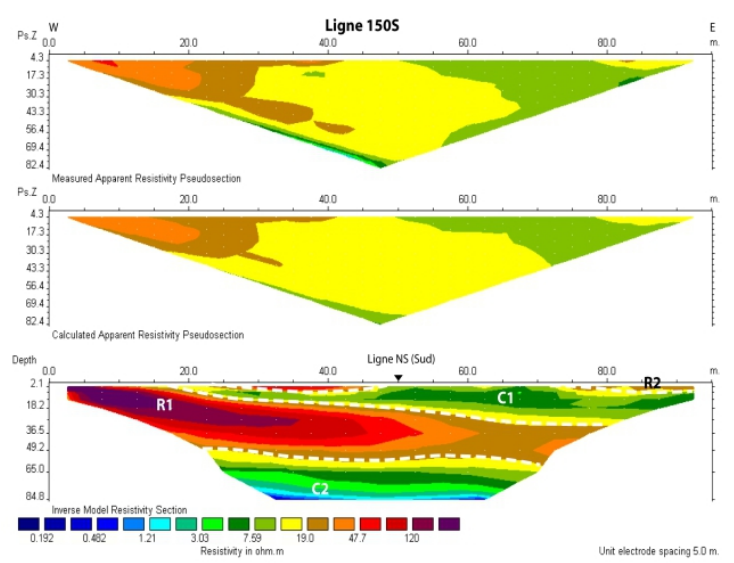

Figure 10: Electrical tomography survey: Line $150 \mathrm{~S}$

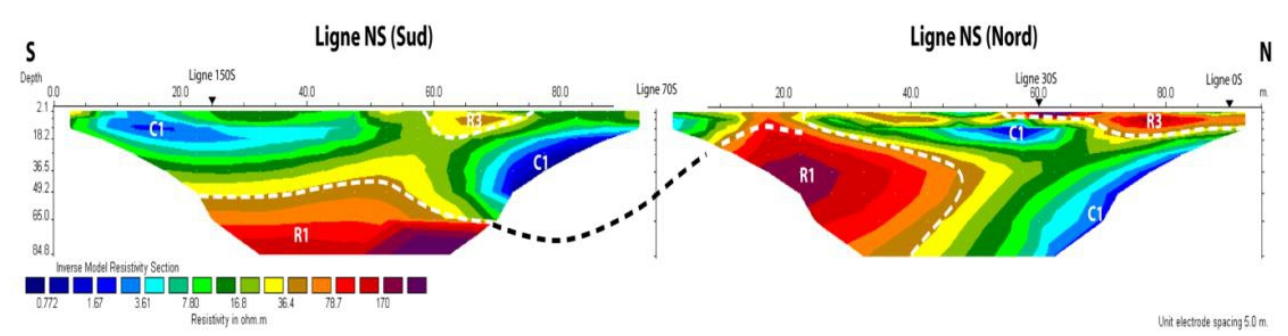

Figure 11: Electrical tomography survey: Line NS (South) and NS (North) 


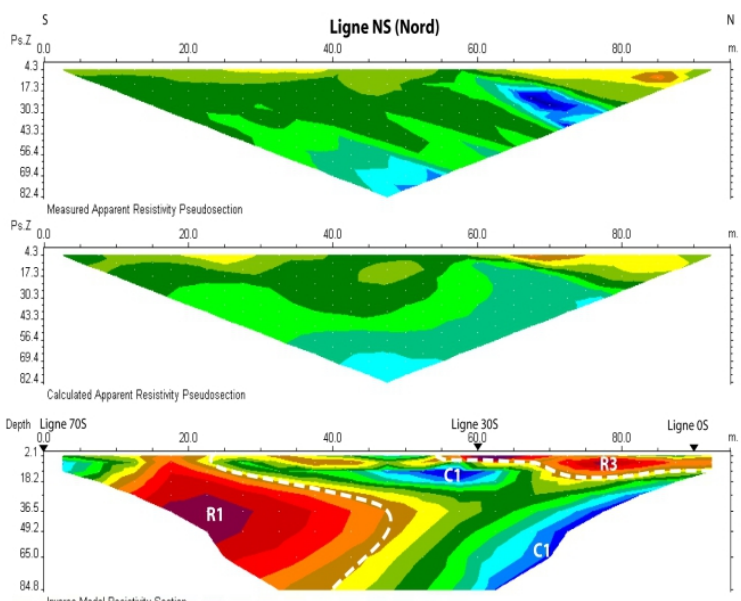

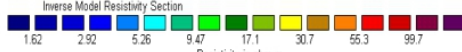

Figure 12: Electrical tomography survey: Line NS (North)
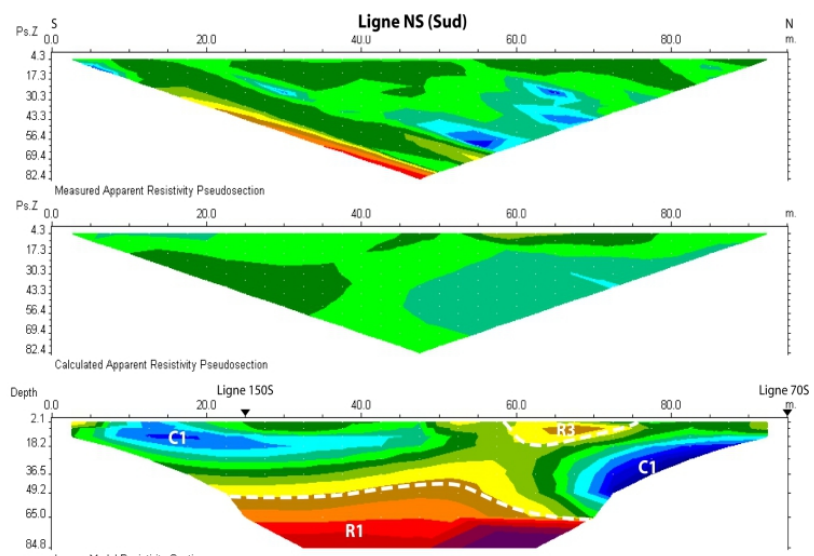

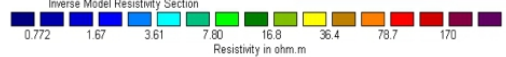

Figure 13: Electrical tomography survey: Line NS (South)
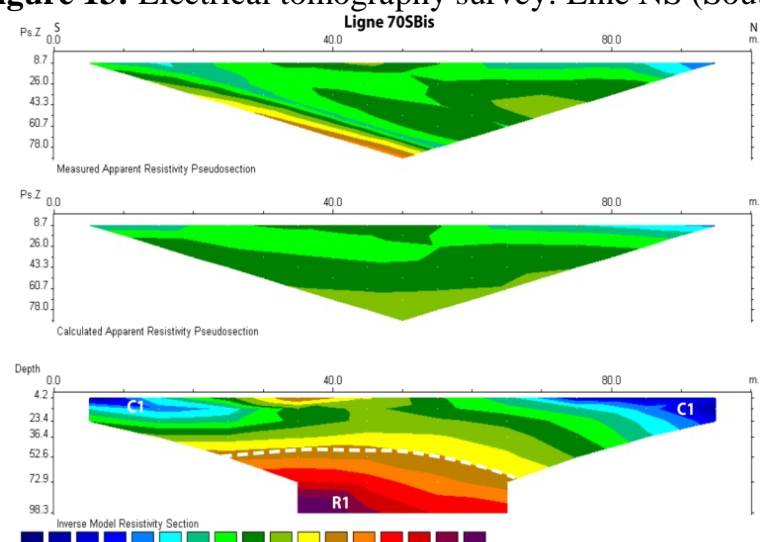

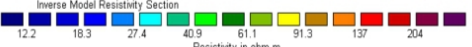

Figure 14: Electrical tomography survey: Line 70S Bis 


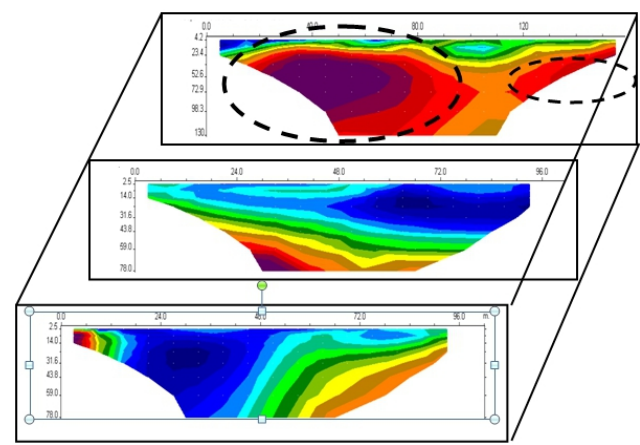

Figure 15: Block diagram obtained from the sector 2 profiles

The block diagram obtained from the resistivity panels made in sector 2 of the site showed the presence of two different anomalous ranges:

- A strong range materialized by strong values of apparent resistivity values (over 400 ohm.m) particularly in the northern section. This anomaly was spotted to the right of mineralization observed in the old gallery. Therefore, we believe that the copper mineralization is continuous in the northern part of at least 15 meters from the old gallery. This result needs to be confirmed by a reconnaissance survey.

- A conductive pad in the center of Sections 13 and 14, and also extending the profile 12 , the values of the observed resistivity show the presence of marl intrusions, locally observed in the sub-sector 2 .

\section{Method of operation}

In general, for the exploitation of thin veins, several methods are used in functions of a number of technical and economic criteria.

- The wall rocks consist of less altered basalts

- The dip of the mineralization is of the order of $45^{\circ}$ to the north

- The Power of the mineralization varies from 0.5 to $2.5 \mathrm{~m}$

- The extension of the mineralized zone is very important

- The concentration of the mineralization is variable

Therefore, a well-suited method generates the vicinity of mining operations low stress concentrations. It leads to an optimal air circulation and uses the best natural forces, especially gravity, while ensuring a reduced maintenance costs. It also seeks to minimize the impact of mining operations on the operating environment (landslides, mine water etc.)

Take into account the above data, we recommend first time scraping and open pit excavation work will relishes to retrieve it easily accessible ore. In parallel, the use of inclined wells and hillside galleries, allowed inclined to follow the deposit to the wall, thus reducing the importance of crosscuts 
.These wells will be spaced 50 meters along the dip and serve for the service of each panel forming the main levels. The latter are themselves divided into sub-levels of 20 meters and communicate with each other through ventilation chimneys.

\section{Discussion}

The collision of Gondwana with Laurentia craton Baltic and several other microcontinents led to the creation of the supercontinent Pangaea, surrounded by the Pacific Ocean (Panthalassan) and during the late Paleozoic. This development was followed by a new round of Wilson. This is his dislocation Triassic upper with extensive episodes, creating ponds within a intracontinental rift at the northwest boundary of the African plate. These basins evolve later rifting mode to the drifting mode with relative motion of Africa to the east, followed by tectonic inversion, filling pools and finally lifting the entire Atlas region.

This general situation gives the development of the Atlas intracontinental chain. Relations between tectonic deformation and post-rift and syn sedimentation have been a recurring theme and in regional research both in terms of lithology, stratigraphy, petrography, tectonics, and even regional mapping (DU DRESNAY 1975; COUSMINER \& MANSPEIZER, 1976; 1984; BEAUCHAMP, 1988, 1996; MANSPEIZER, 1978; Lorenz, 1988; Souhel 1989, 2000; PIQUE, 1998; HAFID, 2000; CANEROT, 2002; HADDOUMI, 2002; Laville, 2002 Ellouz, 2003; Brunet, 2003; ARBOLAYA, 2003; CHARRIERE, 2009).

In all previous research, it seems clear that the evolution of the Atlas system is run by three separate major tectonic events. This is first of two extensive processes: first, the opening of the Tethys Ocean, from the Upper Triassic and the formation of its southern margin, with structural orientation generally east-west. Second, the early rifting of the central Atlantic from the Triassic (. HUON et al 1993), with a north-east - south-west tectonic structures (Laville \& PIQUE, 1991; CHARRIERE, 1996; et al FISH, 1998).

These two directions, east and west of the Tethys and northeast southwest of the Atlantic have played a vital role and reflect the structure of the Upper and Middle Moroccan Atlas. It is striking that management Tethyan is that of the Middle Atlas, while the High Atlas is moving, he, according to Atlantic direction. A third main event marks the convergence of the African and Iberian plates, initiating the tectonic inversion of the Atlas intracontinental basins. This is the beginning of the Alpine orogeny from the Upper Cretaceous, with the first compressive structures in Algeria (BOUDJEMA, 1987).

In the Atlas region of Morocco, the latter event left shows the two large inverted basins, the Atlas system (High Atlas, Middle Atlas) and 
existing pools. However, the Atlas system has filled syn- and post-rift basins, Triassic to Tertiary, which is subsequently reversed. Their geographical position more or less corresponds to the current situation of Upper and Middle Atlas (Souhel 1997; Ellouz, 2003).

The Mesozoic cover gradually deposited during the sequence of events and extensive compression that mark the Mesozoic and Cenozoic history of Morocco (Laville et al., 2004). Different areas of the Atlas are mainly controlled by the inherited flaws in the Variscan orogeny (Piqué et al., 2002). Three major phases can beings differentiated in the formations of the Atlas Mountains:

(i) A phase of rifting (220-195 Ma), this phase is associated with the separation of Africa and North America leading to the North Atlantic opening. This stage is marked by the development of many half-grabens in the rift of the Atlas, gradually filled with coarse-grained clastic sediments and by siltstones and evaporite levels (Laville et al., 2004). This phase is also accompanied by a significant tholeiitic basaltic magmatism and whose main phase is dated at $199 \mathrm{Ma}$ (Knight et al., 2004; Verati et al. 2007). These formations belong to the magmatic province of Central Atlantic (CAMP: Central Atlantic Magmatic Province). Mineralization Timghart would likely related to this phase, at least for the initial stock, syngenetic.

(ii) A phase of expansion Toarcian ( 180 Ma) associated with the decoupling of the African plate with Europe plate, a consequence of the opening of Tethyan oceanic domain. It corresponds to the fragmentation of the carbonate platform associated with a transtensive regime and the establishment of the Middle Jurassic intrusions (Piqué et al., 2002). Refocusing and late epigenetic remobilization of copper mineral stock Tighmart.

(iii) A Meso-Cenozoic compressive phase. This phase begins from the Santonian $(\sim 85 \mathrm{Ma})$ by the reactivation of the rift structures and resulted in the Cenozoic uplift of the whole of the Atlas Mountains. This compression is the result of the convergence between the African plate and the European plate began at the end of the Mesozoic Piqué et al. (2002). A second phase of reconcentration has probably affected the mineralization.

\section{Conclusion}

In order to improve the quantity and quality of these resources, we suggest achieving this deposit additional work (delimitation, specific studies of this deposit, the impact on the environment, etc.). Therefore, a program of work farms and recognitions will be executed in the next period of transformation of the permit. The work planned for this year is as follows:

- topographical studies

- Additional egological Studies 
- Mineralogical and geochemical studies

- Analysis and valuation tests

- Prevention and environmental protection measures

- Mining work topographical

Work aims to accurately position the showings and allow access track (tracks, track, gallery, survey implementation, shaping and travels well). This study should enable evaluation indices, the orientation of mining operations and the calculation of reserves in place. The program for the period of transformation of the operating license; focuses primarily on increasing geological knowledge of the different indices and detail their metallogenic memberships and define local and regional metallotects. This study includes part of the exploration ecological surface and deep stratigraphic analysis, geochemical, structural and petrographic.

The objective set for this study is fixed to determine the mineral associations (nature, paragenesis and texture). In addition, it will analyze for $\mathrm{Cu}, \mathrm{Au}$ and $\mathrm{Ag}$ exploited structures and structures in exploration phases.

This work began with scratching and tracing trenches throughout the mineralized vein and then by sinking wells in reconnaissance lowers levels. This work shows that the copper index Tighmart is continuous eastward surface and at depth. This is much crushed zone MF extension (hundreds of meters) or there is a significant concentration of chalcocite associated with malachite and azurite rarely. Mining operations and research provided for in this program target depth recognition of the ore body and also contribute to the preparation and cutting the deposit to highlight a mining potential may constitute a basis for the start of work operating. They concern:

- Conducting a summary geological study of the index of Tighmart;

- A topographic survey;

The execution of reconnaissance work by trenches and galleries all potential outcrops and operating locations, and subsequently to the collection of samples for chemical analysis;

- The opening of clays in east-west direction knife-edge and at the same level resumes shaft sinking and ventilation chimneys;

- The completion of the preparatory work (access tracks personnel and equipment for the disposal of slaughtered products.

\section{References:}

1. Austin, J. H. (1998). Zen and the brain: Toward an understanding of meditation and consciousness. Cambridge, MA: MIT Press.

2. Andreu, B., J.-P. Colin, et al. (2003). Les ostracodes des «Couches Rouges» du synclinal d'Ait Attab, Haut Atlas Central, Maroc: systématique, biostratigraphie, paléoécologie, paléobiogéographie. Revue de Micropaléontologie 46: 193-216. 
3. Arboleya, M. L., A. Teixell, et al. (2004). A structural transect through the High and Middle Atlas of Morocco. Journal of African Earth Sciences 39: 319-327.

4. Bardon, C., A. Bossert, et al. (1978). Paleomagnetisme des formations volcaniques du Cretace inferieur dans l'Atlas de BeniMellal (Maroc). Notes du Service Geologique du Maroc 39(272): 7 26.

5. Beauchamp, J., (1988). Triassic sedimentation and rifting in the High Atlas (Morocco). In: W. Manspeizer (Editor), Triassic-Jurassic rifting. Elsevier, Amsterdam, pp. 477-497.

6. Beauchamp, W., (1996). Intracontinental Rifting and Inversion: Missour basin and Atlas Mountains, Morocco. AAPG Bulletin, 80(9): 1459-1482.

7. Brede, R. (1992). Structural aspects of the Middle and the High Atlas (Morocco); phenomena and causalities. Geologische Rundschau 81(1): 171 - 184.

8. Brunet, M.-F. and S. Cloetingh (2003). Integrated Peri-Tethyan Basins studies (Peri-Tethys Programme). Sedimentary Geology 156: $1-10$.

9. Chafiki, D., J. Canérot, et al. (2004). Les monticules micritiques sinemuriens sur la transversale de Midelt-Errachidia (Haut Atlas Central, Maroc). Estudios Geologia 60(3-6): 139-152.

10. Canérot, J., B. Andreu, et al. (2002). Mesozoic carbonate platforms andassociated siliciclastic spreadings in Morocco North African Cretaceous rudists and coral formation sand their contributions to carbonate platform development, Tunisia. Nato Advanced Research Workshop (ARW): 13-14.

11. Charrière, A. (1992). Discontinuites entre les «couches rouges» $d u$ Jurassique moyen et du Cretace inferieur dans le Moyen-Atlas (Maroc). Translated Title: Discontinuities between Middle Jurassic and Lower Cretaceous red beds of the Middle Atlas, Morocco. Comptes Rendus de l'Academie des Sciences Serie 2 Mecanique Physique Chimie Sciences de l'Univers Sciences de la Terre 315(11): 1389 - 1396.

12. Charrière, A., B. Andreu, et al. (1998). La transgression $d u$ Cénomanien supérieur dans la Haute Moulouya et le Moyen Atlas méridional, Maroc. Geobios 31(5): 551-569.

13. Charrière, A., H. Haddoumi, et al. (2005). Découverte de Jurassique supérieur et d'un niveau marin du Barrémien dans les «couches rouges» continentales du Haut Atlas central marocain: implications paléogéographiques et structurales. Compte Rendus Palevol 4: 385394. 
14. Charrière, A., Haddoumi, H., Mojon, P.O., Ferrière, J., Cuche, D. \& Zili, L. 2009. Evidence of Paleocene unconformable deposits with charophytes and ostracods on the anticline ridges of the Imilchil area (High Atlas, Morocco): Paleogeographic and structural implications. Comptes Rendus Palevol, 8, 9-19.

15. Choubert, G. and A. Faure-Muret (1962). Evolution du domaine atlasique marocain depuis les temps paléozoieques, livre à la mémoire du Prof. P. Fallot. Mémoire hors-série service de la Société géologique de France 1: 447 - 514.

16. Cousminer, H.L. and W. Manspeizer. (1976). Triassic pollen date Moroccan High Atlas and the incipient rifting of Pangaea as Middle Carnian. Science 191: 943-945.

17. Du Dresnay, R., (1963). Données stratigraphiques complementaires sur le Jurassique moyen des synclinaux d'El Mers et de Skoura (Moyen-Atlas, Maroc). Bulletin de la Société géologique de France 5(6): 893-900.

18. Du Dresnay, R., (1969). Discussion stratigraphiques sur les conditions de gisement de bois fossiles mésozö̈ques du Maroc, étudiés par Mlles. Y. Attims, F. Crémier et F. Gazeau. Notes du Service Geologique du Maroc 210: 121-179.

19. Du Dresnay, R., (1971). Extension et développement des phénomènes récifaux jurassiques dans le domaine atlasique, particulièrement au Lias moyen. Bulletin de la Société géologique de France 7(XII): 4656.

20. Du Dresnay, R., (1972). Sédiments carbonatés intercotidaux et supracotidaux du Lias inférieur dans le domaine atlasique marocain. C. R. Acad. Sci., 275: 341-343.

21. Du Dresnay, R., (1972). Les phénomènes de bordure des constructions carbonatées du Lias moyen du Haut Atlas oriental (Maroc). C. R. Acad. Sci. Paris, 275(S): 535-537.

22. Du Dresnay, R.. (1975). Influence de l'heritage structural tardihercynien et de la tectonique contemporaine sur la sédimentation jurassique, dans le sillon marin du Haut Atlas, Maroc. IXème Congres international de sédimentologie 4, Nice: 103 - 108.

23. Du Dresnay, R., (1976). Les structures en "tipis" liées aux faciès carbonatés intertidaux et supratidaux du Lias inférieur, dans le domaine des chaînes atlasiques du Maroc. Comptes rendus de l'Académie des sciences Paris 282(23): 2059-2062.

24. Du Dresnay, R., (1979). Sédiments jurassiques du domaine des chaînes atlasiques du Maroc. Symposium « Sédimentation jurassique W européen », Association des sédimentologues française, Publication spéciale 1: 345-365. 
25. Du Dresnay, R., (1988). Recent data on the Geology of the Middle Atlas (Morocco). in: The Atlas System of Morocco, Springer-Verlag, p. 293-320.

26. Dubar G., (1962). Notes sur la paléogéographie du Lias marocain (domaine atlasique), livre à la mémoire du Prof. P. Fallot. Mémoire hors-série service de la Société géologique de France 1: 529-544.

27. Dubar, G. \& R. Mouterde (1961). L'Aalénien et le Toarcien terminal du Haut-Atlas. Esquisse paléogéographique. Bulletin de la Société géologique de France 7 (20): 169-178.

28. Dubar, G. \& R. Mouterde (1978). Etudes paéontologiques sur le Lias du Maroc: Les formations à Ammonites du Lias moyen dans le HautAtlas de Midelt et du Tadla. Notes \& Mémoires du Service Géologique du Maroc 274: 113.

29. El Arabi, E. H., J. B. Diez, \& al. (2006). Première caractérisation palynologique du Trias moyen dans le Haut Atlas ; implications pour l'initiation $d u$ rifting téthysien au Maroc. Compte Rendus Geoscience 338: 641-649.

30. ELLOUZ N., PATRIAT M., GAULIER J.-M., BOUATMANI R., SABOUNJI S., (2003), From rifting to Alpine inversion: Mesozoic and Cenozoic subsidence history of some Moroccan basins, Sedimentary Geology, 156, pp. 185-212.

31. Ettachfini, E. M., A. Souhel, et al. (2005). La limite CénomanienTuronien dans le Haut Atlas central, Maroc."Publié dans Geobios 38: 57-68.

32. Feist M., Charrière A. \& Haddoumi H. (1999). Découverte de charophytes aptiennes dans les couches rouges continentales $d u$ Haut-Atlas oriental (Maroc). Bulletin de la Société géologique de France, Paris, t. 170, $\mathrm{n}^{\circ}$ 5, p.611-618.

33. Haddoumi, H., A. Charrière, et al. (2002). Nouvelles datations (Hauterivien supérieur-Barrémien inférieur) dans les "Couches rouges» continentales du Haut Atlas central marocain ; conséquences sur l'âge du magmatisme et des structurations mésozoïques de la chaîne Atlasique. Compte Rendus Palevol 2002: 259-266.

34. Haddoumi, H., A. Charrière, et al. (2008). Les dépôts continentaux du Jurassique moyen au Crétacé inférieur dans le Haut Atlas oriental (Maroc): paléoenvironnements successifs et signification paléogéographique. Carnets de Géologie / Notebooks on Geology.

35. Hafid, M., (2000). Triassic-early Liassic extensional systems and their Tertiary inversion, Essaouira Basin (Morocco). Marine and Petroleum Geology, 17(3): 409-429. 
36. Hailwood, E. A. and J. G. Mitchell (1971). Paleomagnetic and radiometric dating results from Jurassic intrusions in South Morocco. Geophysical Journal of the Royal Astronomical Society 24: 351-364.

37. Hoepffner, C., Soulaimani, A., et Piqué, A., (2005). The Moroccan Hercynides. In: Catuneanu,O., et Guiraud, R., Editors, Phanerozoic evolution of Africa (special issue). J. Afr. Earth Sci. 43, 144-165.

38. Huon, S., Cornée, J.J., Piqué, A., Rais, N., Clauer, N., Liewig, N., \& Zayane, R. (1993). Mise en évidence au Maroc d'événements thermiques d'âge triasico-liasique liés à l'ouverture de l'Atlantique. Bull. Soc. géol Fr. 164

39. (1993), pp. 165-176.

40. IBOUH H., MICHARD A., HIBTI M et \& EL AMARI K. (2011). Le cuivre des Couches Rouges de Tansrift (Atlas d'Azilal). NOUVEAUX GUIDES GEOLOGIQUES ET MINIERS DU MAROC - VOLUME 9, LES MINES DU HAUT ATLAS CENTRAL.Volume spécial des notes et mémoires du service géologique du Maroc. P. 281-286

41. Jacobshagen, V. H. (1986). Untersuchungen zur geodynamischen Entwicklung des Atlas Systems in Süd-Marokko. Berliner Geowissenschaftliche Abhandlungen Reihe A 66(2): 265-272.

42. Jacobshagen, V. H., Ed. (1988). The Atlas System of Morocco. Studies on its Geodynamic Evolution. Lecture Notes in Earth Sciences. Berlin-Heidelberg-NewYork, SpringerVerlag.

43. Jacobshagen, V. H. (1988a). Geodynamic evolution of the Atlas System, Morocco: an Introduction. The Atlas System of Morocco. Studies on its Geodynamic Evolution. V. Jacobshagen. BerlinHeidelberg-New York, SpringerVerlag. 15: 481-499.

44. Jacobshagen, V. H. (1988b). Zur Bau-Geschichte des zentralen Hohen Atlas (Marokko)." Berliner Geowissenschaftliche Abhandlungen Reihe A 66 (2): 455-470.

45. Jacobshagen, V. H. (1992). Major fracture zones of Morocco: The South Atlas and the Transalboran fault systems. Geologische Rundschau 81(1): 185-197.

46. Jenny, J., A. Le Marrec, et al. (1981). Les couches rouges $d u$ Jurassique moyen du Haut Atlas central (Maroc): corrélations lithostratigraphiques, éléments de datations et cadre tectonosédimentaire. Bulletin de la Société géologique de France 23(6): 627639.

47. Jenny, J. (1988). Mémoire explicatif de la carte géologique du Maroc au 1/100.000 (feuille d'Azilal, Haut- Atlas central). Notes \& Mémoires du Service Géologique du Maroc. 339 bis. 
48. Knight, K.B.; Nomade, S.; Renne, P.R.; Marzoli, A.; Betrand, H.; Youbi, N. (2004). The Central Atlantic magmatic province at the Triassic-Jurassic boundary: paleomagnetic and 40Ar/30Ar evidence from Morocco for brief, episodic volcanism. Earth and Planetary Science Letters 228: 143-160.

49. Laville, E. (1981). Rôle des décrochements dans le mécanisme de formation des bassins d'effondrement du Haut Atlas marocain au cours des temps triasiques et liasiques. Bulletin de la Société géologique de France 23(3): 303-312.

50. Laville, E. and J.-P. Petit (1984). Role of synsedimentary strike-slip faults in the formation of the Moroccan Triassic basins. Geology 12: 424-425.

51. Laville, E. and A. Piqué (1991). La distension crustale atlantique et atlasique au Maroc au début du Mésozö̈que: le rejeu des structures hercyniennes. Bulletin de la Société géologique de France 162(6): 1161-1171.

52. Laville, E., A. Piqué, et al. (2004). A restatement of the Mesozoic Atlasic Rifting (Morocco). Journal of African Earth Sciences 38: 145153.

53. Le Marrec, A. (1985). Carte géologique du Maroc à 1:100 000, feuille Demnat. Notes \& Mémoires du Service Géologique du Maroc.

54. Lorenz, J. C. (1976). Triassic Sediments and Basin Structure of the Kerrouchen Basin, Central Morrocco. Journal of Sedimentary Research 46: 897-905.

55. Lorenz, J. C. (1988). Synthesis of Late Paleozoic and Triassic redbed sedimentation in Morocco. The Atlas System of Morocco: Studies on its Geodynamic Evolution. V. H. Jacobshagen. 15: 139-168.

56. Löwner R. (2009). Recherches sedimentologiques et structurales à l'articulation entre Haut et Moyen Atlas et la Haute Moulouya, Maroc. Doctorat, Université Technique de Berlin, 201 p.

57. Manspeizer, W., J. H. Puffer, and Cousminer, H.L., (1978). Separation of Morocco and eastern North America: A TriassicLiassic stratigraphic record. Geological Society of America Bulletin 89 (6): 901-920

58. Mattauer, M., P. Tapponnier, et al. (1977). Sur les mécanismes de formation des chaînes intracontinentales. L'exemple des chaînes atlasiques du Maroc. Bulletin de la Société géologique de France 19(3): 521-526.

59. Mattis, A. (1977). Non-marine Triassic sedimentation, central High Atlas Mountains, Morocco. Jour. Seg.Petrology,47, p. 107-119.

60. Michard, A. F. (1976). «Elements de géologie marocaine.» Notes \& Mémoires du Service Géologique du Maroc 252: 408. 
61. Mohr, B. and G. Seufert (1987). Mittel jurassische Rotsedimente im zentralen Hohen Atlas, Südmarokko; Geologische und palynologische Untersuchungen.» Neues Jahrbuch für Geologie und Palaeonthologie 173(3): 303-319.

62. Piqué, A. and E. Laville (1993). Les séries triasiques du Maroc, marqueurs $d u$ rifting atlantique. Comptes rendus de l'Académie des sciences Paris 317(9): 1215-1220.

63. Piqué, A. et al., (1998). Evolution structurale des domaines atlasiques du Maghreb au Méso-Cénozoique ; le rôle des structures héritées dans la déformation du domaine atlasique de l'Afrique du Nord. Bull. Soc. Geol. Fr., 169: 797-810.

64. Piqué, A. et al., (1998). Le poinçon maghrébin: contraintes structurales et géochimiques. C. R. Acad. Sci. Paris, 326: 575-581.

65. Piqué, A. et al., (2002). The Mesozoic-Cenozoic Atlas belt (North Africa): an overview. Geodinamica Acta, 15(3): 185-208.

66. Poisson, A., Hadri, M., Milhi, A., Julien, M. and Andrieux, J., (1998). The central High Atlas (Morocco). Litho- and chronostratigraphic correlations during Jurassic times between Tinjdad and Toufnite. Origine of subsidence. Peri-Tethys Memoire 4 - Mem. Mus. Hist. Nat., 179(237-256).

67. Septfontaine, M. (1984). «Biozonation (à l'aide de foraminifères imperforés) de la plate-forme interne carbonatée liasique du Haut Atlas (Maroc).» Revue de Micropaléontologie 27(3): 209-229.

68. Septfontaine, M. (1986). "Milieux de dépôt et foraminifères (Lituolidés) de la plate-forme carbonatée du Lias moyen au Maroc.» Revue de Micropaléontologie 28(4): 255-289.

69. Souhel, A. et al. (1986). Précisions stratigraphiques et sédimentologiques sur le Jurassique moyen - supérieur et le Crétacé inférieur - moyen du synclinal d'Ait Attab (H.A.C.). Revue Fac. Sci. de la Terre Univ. Marrakech, 2, 463-477, Marrakech.

70. Souhel, A. (1987). Dynamique sédimentaire des couches rouges intercalcaires (Bathonien Cénomanien) dans l'Atlas de Beni Mellal (Haut Atlas central, Maroc). Thèse du 3ième cycle, Université Paul Sabatier, Toulouse, Strata 2/8, 173p.

71. Souhel, A. and J. Canérot (1989). "Polarités sédimentaires téthysienne puis atlantique: l'exemple des couches rouges jurassicocrétacées du Haut Atlas central (Maroc)." Sciences Géologiques Mémoires, Colloque francomarocain de Géologie 84(2): 168-174. 